INTERNATIONAL HIGHER EDUCATION Number 75 Spring 2014

Pages 25-27

\title{
Internationalization of Higher Education in Post-Soviet Ukraine
}

\author{
VALENTYNA KUSHNARENKO and SONJA KNUTSON
}

Valentyna Kushnarenko is research associate at the Ontario Institute for Studies in Education, University of Toronto, Canada. E-mail: val.kushnarenko@utoronto.ca. Sonja Knutson is director at the International Centre, Memorial University of Newfoundland, Canada. E-mail: sknutson@mun.ca.

The Ukrainian Ministry of Education, Science, Youth, and Sports has been encouraging international initiatives that support Ukraine's aspirations to be recognized in the global higher education arena, primarily focused on Europe. While the recent decision is not to sign a trade agreement with the European Union, the country is facing increasing pressure to choose its future alliances, and this will have an impact on the directions of internationalization. On November 24, 2013, Ukrainian students declared a strike and marched from their universities to the central squares of the major Ukrainian cities, protesting the decision not to sign the EU Association Agreement at the Vilnius Summit-2013. Such pressures urge post-Soviet universities to become specific in defining their internationalization priorities and to enhance the articulation of an international purpose, vision, and operations. 


\section{BACKGROUND}

Ukraine is located between the European Union states and Russia and while not a central player in international education, it maintains a reputation as a country with high standards of teaching and learning. Higher education is perceived by Ukrainians to achieve professional distinction, economic independence, and freedom. During the first week of the 2013 university admission campaign, Ukrainian public universities registered more than 600,000 applications. At an April 2014 international education fair, organized by the Ministry of Education, Science, Youth and Sports of Ukraine, foreign universities are advised that they can access over 8,000 potential students over a three-day period in Kiev alone (edu-abroad.com.ua). While law, business management, economics, and marketing have traditionally been the most popular fields of study, Ukrainian students today are looking to study abroad in finance, information technologies, hotel/hospitality management, tourism, fashion and interior design, and other fields new to the average Ukrainian postsecondary offering. In contrast to the Soviet period when students prioritized entering any university (preferably a Kyiv one) to earn a diploma, current Ukrainian high school graduates choose a particular university with a competitive field of study and affordable international outreach programs. Universities that can provide pathways to a quality international credential encourage Ukrainian freshmen to prefer schools with strong international partnerships.

For a growing demand to intensify students' international opportunities, Ukrainian universities are motivated to regroup and balance available resources, to secure their own international niche. Searching for internationalization markets, Ukrainians anticipate European Union and Russian directions. While 
criticized for protracted partnership negotiations, universities respond with their careful approach to international standards and quality assurance and the importance of prioritizing national versus international in reorganization of their institutions into "world class" universities.

When Ukrainians mention "internationalization" of higher education, they usually mean "Europeanization." Faculties define internationalization in the regional European terms and highlight the importance to sustain a future oriented process of bringing up their students in the spirit of the "United Europe: the Economy of Knowledge and Pan-European Cultural Heritage." In May 2005, Ukraine accepted an official European Union invitation to join a Bologna declaration in order to participate in "the harmonization of a European higher education's architecture via compatibility and comparability of the regional education systems." An increase in the interest of online courses or courses conducted at partner institutions, which can supplement home university curricula-for example, through participation in the European Union TempusTacis's projects and programs, the Erasmus-Mundus Programme on research, pedagogy, and professional training, the Grundtvig Programme on adult education, and the Comenius Sub-Programme on the Lifelong Learning.

\section{Current Context}

A new version of the Law on Higher Education (December 2012) and the National Doctrine for Development of Education: Ukraine-XXI Century (April 2002) calls for the creation of more innovative and effective international academic partnerships in the Ukraine. Partnerships that create opportunity for joint research and mobility of researchers allow universities to respond to the 
new context of competition on a global scale-in particular, when it comes to employability of graduates and the attraction of research partners and external funding. Ukrainian faculty and students express some skepticism about government interventions or proclamations around internationalization, but an overwhelming majority of students have indicated a desire to go abroad for studies, with the expectation of increased employability. Currently, more than 25,000 students from Ukraine study abroad (Study.ua). They mention Malta, Italy, the United States, Australia, New Zealand, and Canada as preferred future academic destinations.

Institutionally, Ukrainians concentrate in three directions: (a) senior administration-led strategic internationalization, (b) development of international components of the national curriculum, and (c) organizational restructuring. Programmatically, they prioritize joint curriculum development initiatives. Yet, Ukrainians are also engaged in faculty and student exchanges, International Summer Institutes, cocurricular activities (conference presentations, campus events, and visiting international faculty, etc.), foreign language studies, and international research. The creation of the International Consortium of Ukrainian Universities, "The Knowledge Triangle: Education-ResearchInnovation," is a major step forward in cross-border collaboration to promote knowledge and technologies transfer-in this case with Poland, primarily. New efforts aimed at collaboration with Great Britain, Switzerland, France, Germany, Spain, Sweden, Austria, and others will see the ongoing development of joint/dual degree science and technology programs. Canada is also on the radar with its growing expertise in natural resource exploration, to extraction and accompanying environmental research. The current evolution of joint/dual 
degree projects depicts the Ukrainian universities' most ambitious aims to harmonize degree qualifications with the West.

To promote global academic interconnectedness while avoiding brain drain, most Ukrainian universities need serious structural and organizational changes. Several issues impede a coordinated, strategic approach to sustainable internationalization and reciprocal mobility. Clumsy or ambiguous ministerial internationalization policy directions reduce motivation. University administration, with labor-intensive operational regulations, creates a growing pressure on resources. The demand for accountability compounded by weak international program management means few will risk comprehensive change. Universities are already performing at maximum infrastructural, financial, and human resource potential-making it difficult to explore opportunities to position themselves globally. Collaborating on missions abroad to network in new countries, as in the recent delegation to the 2013 Conference of the Canadian Bureau for International Education in Vancouver, provides hopeful directions but requires strong leadership and foreign funding assistance.

Internationalization of the Ukrainian academic agenda parallels the journey of many other countries in their roles as drivers for general reform of higher education. Without a motivating factor, national educational reform (in terms of streamlining credit transfer, institutional internal restructuring processes, etc.) is difficult to initiate and achieve. Internationalization, encompassing as it does the positioning of an institution within the global context, becomes a driver for general reform. Without this reform, internationalization is hindered by lost momentum-due to existing barriers in strategic planning, productive distribution of financial and human resources, and 
identification of operational activity targets. If done constructively, with the continued support of international partners, such improvements may offer Ukraine as a model for innovations in higher education among post-Soviet states. 